\title{
FRACTIONS IN URBAN AND COLLECTIVE MEMORY AND TRANSFORMATION OF PUBLIC SPACE: THE HARBOR EXAMPLE IN THE KYRENIA TOWN
}

\author{
Ümmü ALTAN BAYRAKTAR*
}

\begin{abstract}
Nowadays, under the impact of modernization and capitalism, material, social and individual life change in a major pace and scale. The change and evolution of our living spaces in the same pace and scale have lead the people to question the dynamics between past and present. Thus; making research on the relationship between memory and space has brought up; apart from the other studies, the interest to understand the existence of city centers that ensure the sustainability of city and urbanism as a public space, their change and transformation has increased. As a result of recent steps on the economic rationality logic, historic- cultural heritage and historic urban patterns have started to be lost. This change and transformation caused fragments in urban and collective memory and stopped the public spaces being living spaces. 'Harbor' located in the city of Kyrenia in Cyprus is covered under the scope of this study with its change throughout historical process, physical and social features from the aspects of fragments within urban and collective memory and space and power in the transformation of public space. The theoretical basis of the study is aimed to be the concept of Public Sphere by Jürgen Habermas and Collective Memory by Maurice Halbwachs.
\end{abstract}

Keywords: Public Sphere, Space, Power, Collective Memory, Transformation.

\section{KENTSEL VE KOLEKTIF BELLEKTE KIRILMALAR VE KAMUSAL ALANIN DÖNÜŞÜMÜ: GİRNE ŞEHRİ LIMANI ÖRNEĞİ}

\section{Özet}

Günümüzde modernleşme ve kapitalizm etkisinde, maddi, toplumsal ve bireysel yaşam büyük bir hız ve ölçekle değişmektedir. Yaşamlarımızın geçtiği mekanların da aynı hız ve ölçekle değişip dönüşmesi, insanların geçmiş ile bugün arasındaki dinamikleri daha fazla sorgulamasına neden olmuştur. Bu da bellek ve mekan arasındaki ilişkiyi araştırmayı gündeme

* Girne American University, Faculty of Communication, Journalism and Broadcasting Department, Senior Lecturer, Dr. 
getirmiş; diğer çalışmaların yanında, kamusal alan olarak kentin ve kentselliğin sürdürülebilmesini sağlayan kent merkezlerinin çok katmanlı tarihi dokusunun varlığı, geçirdiği değişim ve dönüşümü anlama çabalarını arttırmıştır. Günümüzde ekonomik rasyonalite mantığıyla atılan adımlar sonucunda tarihsel-kültürel miras ve tarihsel kentsel dokular yitirilmeye başlanmıştır. Bu değişim ve dönüşüm kentsel ve kolektif bellekte kırılmalar yaşanmasına ve kamusal alanların yaşanan mekanlar olmaktan çıkmasına neden olmuştur. Kıbrıs'ın Girne Şehri’nde yer alan 'Liman', tarihsel süreç içerisindeki gelişimi, fiziki ve sosyal özellikleriyle kentsel ve kolektif bellekte varolan kırılmalar ve kamusal alanın dönüşümünde mekan ve iktidar açısından bu çalışma kapsamında ele alınmıştır. Çalışmanın kuramsal alt yapısı Jürgen Habermas'ın Kamusal Alan ve Maurice Halbwachs'ın Kolektif Bellek kavramı üzerine kurulmaya çalışılmıştır.

Anahtar Kelimeler: Kamusal Alan, Mekan, İktidar, Kolektif Bellek, Dönüşüm

\section{INTRODUCTION}

Modernization and capitalism change the financial, social and personal life in a fast manner and significant scale. Our changing life styles change the spaces that we spend our lives fast as well. Together with the increasingly fast change in $20^{\text {th }}$ century, the capitalist world sees the space as a tool that will increase the profitability just like in any other thing. The spatial development in each scale and nature that is objectivized is affected from this continuous destructive power of capitalism. Through this impact, it is reflected as fast and comprehensive urban developments and new living spaces and transformation of old, familiar living spaces by re-describing the urban spaces.

This fast change and transformation have made people to question and understand the dynamics between past and present more. Therefore; the issue of making research on the relationship between memory and space have revived, and of being in continuity relationship of memory with space generated from each other has provided a basis for new discussions within many discipline areas and added a new dimension to researches.

When we look at the general overview of today's cities and urban spaces; it is possible to see that the investments that cannot protect the identity and historical and natural heritage, and have been made with economic rationale have become similar to each other as a result of unplanned developments. This change causes fragments in urban and collective memory and transformation in public spaces.

The role of public spaces particularly the opportunity to create a common memory is significant in the formation of urban identity. While social spaces bring the opportunities to have communication with other people; non-utilization of such areas will diminish the social relationships of people and common values respectively. The sustainability of city and urbanism as a public space is directly linked with the existence of multi-layer historical texture of 
city center and public spaces. Historical places and city centers have crucial significance in the collective memory, which is an important component of public space.

The historical-cultural heritage and archaeological, social, cultural, economic and aesthetic values as well as historical urban textures which are one of the most inputs in the formation of urban identities, ensure a relationship between past and future, facilitate communication between generations and may develop the feeling of belonging somewhere have started to be lost. The change in cities and urban spaces has caused the transformation of public spaces from living spaces to random places. [1]

Today, the provision of aesthetic and economic value to many city centers and spaces via urban projects and implementation of the revitalization of public spaces by adding value into the leading historical, cultural, spatial and architectural values in the memory are the expected policies. Although such practices are performed, the reality that when the main aim of these practices is to put a sole economic value into these centers and spaces, these give service to the capital and its movement in the capital which have the power in today's modern cities.

With the aim of establishing the space where the policies will be performed in accordance with interests and making itself visible in such spaces, the creation of abstract space through the use of physical space and formation of social characteristics have been the objective of governing power that has the dominance of producing spaces, throughout the history. The space as a tool that conveys the existence of power to the citizens, legalize and naturalize the power, is now a stage where ideological transmission takes place. This power in today's modern cities is not the state or military power but capital and its movement within the capital. [2] The public space is identified by the dynamics of this formation style and the formation of culture and space is articulated to the dynamics ensuring the movement of money. Therefore; it is not right to separate the architecture and physical space, which is its object from the prevailing formation processes and address it as independent and non-interactive because architecture is the natural product of dominant formation processes and it is possible to see the prevailing ideology in any period is reflected on the architecture.

In today's economic order, the historical urban textures are only considered for only their potential value in solely tourism industry and are subject to the regulations just to create economic values. The historical urban textures that get a fake identity through the regulations undertaken to create a tourism focal point, and collective memory which is an important component of public area are being destroyed and transformed into environments that have no other feature but giving service to tourism.

While the tourism has had a role as an important income source after II. World War around the world and provided positive impacts on the country economies, the negative impacts caused by unprepared and unplanned development in this field have progressively increased. This created the problems affecting the physical and social environment, but also the negative 
and threatening impacts on handing down the coastal living culture that is assessed under this study, and the Harbor as one of the settlements among the product of this culture, located in Kyrenia town, Cyprus, which is in the Mediterranean region, to the next generations.

The harbor is the most important physical space and indispensable part of life in the settlements located around the Mediterranean area. The Kyrenia Harbor has met a physical need contented with trade and also has become among the most important spaces, which defines the city of Kyrenia through the vital opportunities that it offers. This public space, which ensures the establishment of strongest bond between urban population and sea and gives Kyrenia the identity of being a coastal town, has a symbolic characteristic.

The Kyrenia Harbor, which is one of the images first to think of when it comes to Cyprus and especially the city of Kyrenia, is one of the most important historical places that cover the memories of history and past. With its current physical structure and general image, it can display the unique civilization fossils of various nations with different origin from Ancient Kyrenia.

It is possible to understand the history of a city on the basis of historical and archeological data; and through having information on its physical structure. When the physical structure of Anatolia Peninsula, Cyprus and particularly Kyrenia, we can observe that the first settlement dates go back to 1000 B.C and beyond. The most explicit fact is that not only in Hellenistic Era but also after Alexander the Great and during Roman Rule, we can see the urbanization in Kyrenia just like current district centers and surroundings; and the developments occurring towards the social life.

Like the situation in other settlements of Island throughout its history, the settlement of Ancient Kyrenia has many works, ruins and various cultural heritage from Byzantine Period (AD 324-1119), Frankish Period (1191-1192), Lusignan Empire Period (1373-1464), Republic of Venice Period (1489-1571), Ottoman Empire (1571-1878), British Colony Period (1878-1960) apart from the prehistoric periods identified with the existing archeological excavations, and the traces of these civilizations can be observed as well. Under the framework of such reputation, the island of Cyprus in general and Ancient Kyrenia settlement and surrounding of Harbor in specific are virtually the center of an interesting synthesis of eastern and western cultures from many aspects.

The diversity of historical heritage and peculiarity of the Ancient Kyrenia settlement with its rich and multi-cultural infrastructure and Harbor area are the natural consequence of sovereignty of different nations and administrations from various ethnic origins around this area for a long time. The administrations that had come afterwards to the island of Cyprus, had caused changes and differences by partially contributing on the previous ruins, partially damaging or making some significant changes and additions on social structures. The modifications on forts, which were constructed by Lusignans, done by Venetians and then Ottomans by means 
of repair or castle, wall, bridge additions, are one of the most important examples of such. The prescriptive planning works such as extension of Kyrenia Gate in Nicosia during British Colonial years; construction of a part of Police building, customs and similar government buildings by using the stones remained from the demolished walls; restoration of warehouses constituting castle area and harbor sequence of Ancient Kyrenia, may serve as examples for historical mosaic and cultural combination.

Nonetheless the foundation date of city is not exactly known, it is possible to understand that the buildings from the Byzantine Period had been improved and used in Lusignan, Venetian and Ottoman Periods. Following the invention of gunpowder in Venetian Period, the materials, which ensured endurance, were used in buildings; the existing forts were subject to relievo in accordance with the gunpowder. Kyrenia is divided into two zones as 'Upper and Lower Kyrenia' with the new developments.

For the protection of historical texture of Kyrenia, some measures have been taken in every term; planning activities were taken under control and constructions are somehow given a direction under the formation of 'Regional Ordinances'. There are still similar measures. 'Kyrenia White Region Ordinance' which belongs to the Town Planning Department and Municipality of Kyrenia is very important for the planning projects of Municipality and future of city.

The historical texture and ancient buildings in Kyrenia coast recall an international city. Through the activities and improvements in tourism sector in XXI. Century and investors who pursue the major benefits of their economic expectations, the historical sites have been shaped without the care required for the protection of data from various cultures, and were subject to planning modifications (restaurants, small sized guesthouses, hotel, bar and disco etc.) would consequently have a negative impact on the planning future and structure of Ancient city Kyrenia. [3]

Since the beginning of XVI century, the building forms, paints that were used; prayer neighborhoods and education areas in the settlements, have revealed the characteristic of ethical and cultural differences.

We see that during the Ottoman Period, Ancient city of Kyrenia was divided into a set of neighborhoods on the basis of ethical and religious differences. On one side, there were Agha Cafer Pasha Mosque and neighborhood; while Archangelos Michael Church stands out with the mentioned differences. The mosque formed madrasa, hammam and similar Islamic requirements all around and church developed housing for priests or nuns, school and similar buildings associated with the Church in the same integrity.

As a matter of course, it is expected to see Turkish-Islamic settlements around the Mosque; and Christian neighborhood around the Church surrounding.

From the physical planning aspect, the Islamic and Christian groups reflect their differences through the planning needs in the districts and neighborhoods in which they had lived, and 
buildings. For instance; the windows of a Christian house were painted in blue and of a Muslim house were green. This is not a privilege but is the consequence of a fundamental understanding based on beliefs.

The infrastructure and buildings for basic needs such as inward houses, narrow street, covered market, fountain, waterway and water transfer via drains are some of the Turkish-Islam works that were built in the past in accordance with the climate conditions and come until today.

Apart from the ancient surrounding of Kyrenia that developed without losing its universal characteristics, recent planning activities have concretized the historical texture and cultural structure of the city more. Kyrenia Ancient City has now become a geographical location surrounded by modern buildings. Therefore; Kyrenia grows as a district and ancient area has become almost a small settlement to visit protected its physical structure with the harbor which stayed as it is. [4]

The places such as Historical Harbor site, Kyrenia Castle, Kyrenia Folk Arts Museum, Agha Cafer Pasha Mosque, Archangelos Michael Church, Kyrenia Shipwreck Museum; Marine Martyrs Monument, City Wall Castles, Kavizade Fountain; Baldöken Cemetery, St. Andrew Church, Art and Sculpture Museum have been protected and now used for touristic visiting place in Ancient City Kyrenia.

While there is an increasing interest towards historical places, the tourism throughout the island has put on some momentum due to having especially historical, architectural features and buildings etc. as in other settlements with a coast to Mediterranean Sea, and its long beaches and location in the Mediterranean that offers sea-sand-sun tourism opportunities.

Kyrenia town and harbor settlement have an impact on the cultural memory, image on the settlement with its physical heritage and it ensures that people can have a relationship with the past. As it applies for whole island, the most important aspect is to make Kyrenia and harbor area a place to live in by protecting their historical aspects with the economic income from tourism. The utilization from tourism is primarily based on the arrangements to be undertaken in compliance with the natural environment, cultural heritage, social and economic structure of settlement. Otherwise; the tourism will arise many problems without any solutions and remedies instead of benefits. [5]

Nowadays the regulations have created a reality which pushes the historical sites around Kyrenia town and harbor area into a destructive change process, demolishes collective memory which is an important component of public space, serves to capital and its movement, creates an environment that only belongs to tourism purposes. The phases of Kyrenia town and harbor area within the historical process will be assessed and presented together with the social and physical characteristics. 


\section{AIM AND METHODOLOGY}

\section{II.1. Memory, Collective Memory and Public Space}

The systematization of studies on memory had been undertaken especially at the end of $19^{\text {th }}$ century and beginning of $20^{\text {th }}$ century. In this perspective, the impact of Sigmund Freud, Henri Bergson and Maurice Halbwach is distinguished and concept studies are now covered by an inter-disciplinary discussion. There are some approaches that defense the narration of memory as 'individual' and its transfer through representation via images, while some approaches ensures 'the socialization' of concept as an collective formation of society and its use in social sciences as an analytic concept. Thus; Freud considers the remainder and forgetting practices, which are directly linked with memory, as the consequence of personal choices and states that one of the ways for personal protection is the realization of forgetting by the suppression of things that are not desired to be remembered by the subconscious.

In the studies of Bergson, he interprets the memory on the basis of images, which occur in the mind to represent the realities after the perception realized under psychological and cultural impacts-which again such images appear under these impacts. Halbwachs with the term of 'Collective Memory that he developed by being different from the individual memory perspective of his ancestors, referred to collective facts created by society and argued that memory is formed by social codes and individuals cannot be identified without their own social and physical environment. While Halbwachs's approach pave the way to new arguments for various discipline areas; the relationship of collective memory and space are involved closely with the mental synthesizing processes of spatial information over image.

On the other hand, city, which is considered as a significant component of collective memory, shows an inseparable formation with urban spaces, where social interaction within becomes visible. [6] According to Rosi [7], the hypothesis that memory may exist through the social relationships produced by the urban related parts, describes the city as a living creature (urban memory) and enable to interpret the urban spaces as objects of collective memory because urban spaces are not only a formation with physical features but also they are places for daily life that can socially produce.

Another main element in which daily practices and built environment intersect is the concept of public sphere. Yet the role of public sphere obtained in the course of time as well as its relationship between present, past and future brings the public sphere to a point that establish and determine collective memory and urban memory. [8] These spaces of social life that bring urbanites together and invigorate between space and experience has the structure that build the identity of city by its symbolic characteristics. Symbolic spaces with a main role in the representation of city have a significant connective position in social texture that urbanites create in such spaces. [9] Public spheres are the most critical connective elements of relationships that are established between past, present and future. The relationship with past create reference 
points for the relationship with future. Therefore; these spaces are more than establishing identities for cities and they are unique living spaces, which reflect collective memory and urbanity awareness of society. [10]

Public spheres have a significant role in the formation of a society. They are the spaces for social encountering and places where equality conditions are shared, collective memory is generated and mind can develop. In this framework, public spheres are places to face with other members of society, get to develop self-knowledge and identify the society. Therefore collective memory is nourished and sensitivity towards relationship increases. [10]

Today the concept of public spheres is the center of discussions. Its definition and identification of scope is important for social scientists. Jürgen Habermas assessed public sphere, evolution of publicity in history and its forms in different periods in his for study called the Structural Transformation of Public Sphere that was published in 1962. The aim of such historical view is to show the current situation of publicity. When the historical development of public sphere is reviewed, it has 'expanded as an area, but weakened in terms of functionality. [11]

In the framework of city and memory, from the claims that social memory is ideologically produced due to the power and its prospects, restructured each time in accordance with the conditions and manipulated, the issue of questioning the relationships between past and present, and reviewing the change and transformation, remembrance and omission of public spheres in urban areas, which are important and indicative for collective memory and urban identity, on the basis of idea that they are directly related with built environment and daily life practices has become a significant subject.

Based on some findings for social and physical characteristics of the City of Kyrenia in the historical perspective and chronological process of Cyprus as reviewed in the context of study, the destructive aspects of passed phases, which push the historical environment in Kyrenia and surroundings of harbor into a destructive change process, on collective memory as a significant element of public sphere, have been assessed through the philosophers like M. Halbwachs and J. Habermas.

\section{KYRENIA TOWN IN CYPRUS - HISTORICAL EVOLUTION; SOME FINDINGS ON SOCIAL AND PHYSICAL CHARACTERISTICS}

Kyrenia is an important settlement located on the northern coast of Cyprus, which is the third largest island of Mediterranean with $9.250 \mathrm{~km}^{2}$ after Sicily and Sardinia. Cyprus which is close to Turkey with the distance of $65 \mathrm{~km}$; it is $112 \mathrm{~km}$ away from Syria, $162 \mathrm{~km}$ from Lebanon, $418 \mathrm{~km}$ from Egypt and $965 \mathrm{~km}$ from Greece.

Since Kyrenia is a part of island and a settlement area, the review of island from the geological, geographical, sociological and cultural aspects along the chronological process from 
the past until present within the historical perspective of island, is crucial by way of bringing an integral point of view concerning the nature of town that lived within.

According to the researches who discuss the geological structures and phases of island, following the crack of earth's crust, land masses arising from the grikes and placed in the water called 'ocean', had emerged and pressed together onto the water surface by creating ocean floor, and main lands and islands appeared. It is foreseen that Cyprus and other Mediterranean islands in the East Mediterranean had emerged in such evolution.

While the main land of island, Trodos mass (mountains) has stayed as sedimentary rocks in time with the impact of wind and rain; the descending slopes of Kyrenia mountain range has been covered by lime stones. The sand stones of this mountain washed away with rains, have established the infrastructure of Nicosia and Kyrenia.

As a coastal town, Kyrenia, goes along with Trodos and Beşparmak Mountains on the rear front and faces the Mediterranean coast. Kyrenia is located on the northern coast of Beşparmak Mountains of the island of Cyprus within East Mediterranean, and enjoys the benefits of mountain to the utmost while identifying the romance that is reflected through the natural beauties of mountains with its existence.

The first outstanding settlement of Kyrenia's regional structure in its 'neolithic' phase is Çatalköy (Ayios Epiktitos). The said settlement had been identified through the archeological excavations launched in 1960s by the University of Birmingham and Glasgow under the chairmanship of Prof. Dr. Peltenburg. Pursuant to the studies undertaken on the chalcolithic period, Kyrenia was a seaport and a significant coastal line in the Anatolian marine trade. The archeological findings has shown that during the Early Bronze Age and Copper Age, potteries were made from terra cotta and clay all around the Cyprus but especially around Kyrenia and its settlements; knives, pins, stilettos were produced from copper and bronze. It is found out that iron was used instead of bronze during the Iron Age to produce home wares and some agricultural tools; and some small sized iron manufacturing workshops were established under the conditions of that period.

Kyrenia had also been under the socio-cultural effects of many societies, groups and states, which ruled the island in different periods. These historical facts can be understood better when the ecology, city structure and archeological ruins of Kyrenia town are investigated.

Egypt, Mesopotamia, Sumerians, Phoenicians, Hittites which were close to the island of Cyprus; Aegean Tribes, Achaeans, Ionians, Assyrians, Persians, Ptolemaic, Romanians, Arabs, Lusignans, Venetians, Ottomans and British have been the inheritance of a significant history in whole island and especially in the settlements of Kyrenia. All such heritage has created a major historical combination and a nucleus for a joint historical infrastructure. The harbor, wall, castle, housing buildings, religious buildings, trade, warehouse and storehouse buildings are the traces, heritage of physical spaces in Kyrenia coastal town. 
The houses of early Kyrenia were built by using soil and adobe; some houses were built with some boundaries in between while some were built as adjacent; many model buildings that we may call 'row housing buildings' were constructed. Some historians state that such buildings especially inspired by Hittites were distributed in the settlements of Island. It is known that Hittites were made significant social contributions in Cyprus.

Generally the Hittites population were living independent housing. Although there was an obligation to built houses in a dense organization, the exterior walls were separate. When yard was desired, it was placed outside of the house. Most of the houses were single-layered. The building materials were mainly stone, adobe on the walls; roofs were flat and covered with soil. If there is an upper story in houses, the lower story was used as hayloft, shed and workshop. Can't we consider having such houses among the traditional country houses in Cyprus as the ongoing impacts of Hittites? [12]

Many of the houses built in central settlement area of Kyrenia and its surrounding were constructed in Hittite style as buildings and houses built by using soil-adobe and partially stones.

The reflection of unique characteristics of Phoenician civilization, which resided in island, can be observed. Phoenicians, for whom the trade was very important, had created trade centers in small settlements that they had established along coasts. In South, they had used Kitium, Amatus; Laptihos in north, Kyrenia Castle around Kyrenia harbor area as trade center and settlement area. Phoenician trade was performed sea-borne by the ships via Anatolia Peninsula, Syria, Lebanon and North Africa, Egypt and Spain.

Kyrenia Harbor, which is close to the Kyrenia Castle, is surrounded in a lunar shape by the storages, which were built along the coast and served as warehouses. The foundations of aforementioned buildings were based on the old civilizations and subjected to the changes coming through the civilizations of tribes or states that occupied the island and their planning contributions. The warehouses are now used as the storages of bars, cafes, restaurants, guesthouses or luxurious hotels and restaurants. They were used as carob, olive, and wheat, barley warehouses in Ottoman period. In Venetian Period, some warehouses were used for products that were produced and might be sold to foreign countries, like olive, vinegar, zivania, wine and similar alcohol based alcoholic items under some circumstances for short period and as a temporary shelter for the animals which will be transferred to foreign countries. During the early years of Colonial Period, Kyrenia Harbor was used as a shelter and emergency port of fishing boats and as a storage where net and similar fishing equipment, timbers and sawdust, equipment required for making rowboat-small boats were stored. Sometimes it is reported that small boats, boats and similar vessels were protected also in these warehouses.

Due to the competition between civilizations, the monuments of civilizations have been destroyed, and ordinary traditions were applied on the settlers with new concepts. When Aegean people brought their civilization in the island, they preferred to live as it was in Aegean 
islands. Therefore; they objected to the civilization and understandings before them. This was also valid for Aegean and following tribes as well. However; regardless of the destruction level, the foundations of monuments of civilizations were at least protected. Many of monuments, buildings, church and towers were re-constructed on their old foundations.

The time and people who constructed the Kyrenia Castle, which is adjacent to Kyrenia Harbor, located on the northeast of city and built before the sea in a rectangular shape, is not quite known. However; it is regarded that it was constructed on its foundations in different times. The latest version of constructed castle reminds the Venetians. During 307-years of Ottoman period, many architectural modifications had been made in the interior structure of castle; the exterior had a different outlook with some architectural additions via additional gateway and bridge. Although some sources mention that Kyrenia Castle was built for defense purposes by Byzantines against Arab strikes, such information are just assumptions. As a result, the castle is described in three phases with different periods following the structural alterations.

1. Early Byzantine Period Castle (VI-XII century AD), 2. Lusignan Period Castle (1200-1211 AD), 3. Venetian Period Castle (1489-1570 AD) Major part of current castle had been got done by King John D'ibelin between 1208-1211 AD. Byzantine Period fortification was used in the structure. [12]

The castle is an important building used in the defense of Kyrenia. The castle, which encountered with damages throughout the war times, was repaired in each time. The Kyrenia Castle with the military shelter and defense purposes was especially used as a prison during British Colonial Period. Many lawyers and politicians who had outstanding roles in Turkish Cypriot history, many of the Turkish people who rioted against colonial administration were kept in Kyrenia Castle. Thus; Kyrenia Castle is also referred as a prison in history.

Venetian Priest Giovanni Mariti, who stayed in Cyprus between the years of 1760-1767, noted in his work regarding the Ottomon Administration in Cyprus and socio-economic situation when he was working in Larnaca Consulate, that Kyrenia Castle had been used as a crucial shelter point for the protection of city community against Dizdar Halil Rebellion and Çil Osman Incident. [13]

Kyrenia Castle formed by the settlements-developments in different periods, has now become one of the housing and tourism business (refreshment and accommodation) and the focal point of tourism by the spatial data that it presents. [14]

The findings of Italian writer Giovanni Mariti in his book 'Travels in the Island of Cyprus' on the social, economic and ethical structure of island are very interesting. The narration of Mariti on Kyrenia is as follows:

Cerines (Kyrenia) is about 20 miles distant from Nicosia. The town is low populated. The Greek who make up the Christian population of the island have a church, the seat of a bishop; while Turks have a mosque. The government is administered by a commissioner and a judge. 
The inhabitants till the surrounding lands and get their labor's good worth since many springs make this place as one of the fertile regions of Cyprus. Kyrenia region produces wheat, barley, silk, cotton oil and carob; which sends shiploads of latter to Alexandria every year... [13]

Giovanni Mariti also mentioned from the Kyrenia Harbor in his work; it narrated it as a port which stands next to the castle as if it is a pool and can accommodate a couple of ships. [13]

The cities or towns, which were surrounded by the walls were defined with the word of kal'a and specified as kal'a-i Famagusta; kal'a-i Nicosia and kal'a-i Kyrenia. When we say Kyrenia Castle; Famagusta Castle; Nicosia Castle, only the existing known castle is referred. By the word of castle called by the names of towns, the walls surrounding the city are referred. Nicosia, Famagusta and Kyrenia are the settlements in the island, which are surrounded by the walls and have gone down into history as kal'a-i Kyrenia. There are wall exit gates in these cities surrounded by the walls. Paphos Gate; Kyrenia Gate and Famagusta Gate lead the way within the wall and open to the relevant district. The wall gate facing to Kyrenia direction is called 'Kyrenia Gate'; the gate opening towards Famagusta is called 'Famagusta Gate'.

Major part of the walls surrounding Kyrenia was destroyed. The only evidences and witnesses to the existence of walls are some wall towers or another tower on the rear front of fort city, adjacent to the city and not very far away from the harbor.

Dr. William Dreghorn who resided in Kyrenia for long years and then passed away, was known for his drawings and engravings from old Kyrenia, which then he published as a book. The Kyrenia Castle and Kyrenia Harbor was looking interesting in their old status in such drawings. ${ }^{1}$

The late Mr. Hasan Fehmi also had some findings and statements regarding Kyrenia Harbor and castle:

Since the harbor, which was used to be in the shape of horseshoe, was open to the eastern wind, the part opening towards north was closed and a new entrance was constructed on the side of castle. The wall, which goes along the east from the lighthouse, was built in 1962. There is an old lighthouse ruin on the eastern side of harbor. The customs building and dock were built in Colonial Period. When ferry services between Kyrenia-Taşucu have started, a pier was built at the entrance point of harbor for dropping the anchor. There is a new harbor construction on the eastern part of town (this harbor has been constructed and put into service). Current harbor is only used for yachts. (14)

Kyrenia Harbor, which was a significant coastal town in Middle Age and located on a area intersecting the trade routes of Europe, Middle East and Far East and North Africa, lost its duty and old reputation as a transfer point with the discovery of new trade routes. New harbors

1 Dr. William Dreghorn had gifted a part of his own drawings and engravings to Kyrenia Directorate of National Archive and Research Department for the use of researchers before his death. 
were constructed covering the functions required the era and located outside of the historical settlements including this harbor which become out of service by the $20^{\text {th }}$ century. [14]

Apart from being the most important entrance gates for towns founded on waterfronts to the outside world since the ancient eras, the harbors are crucial focal points where trade is performed, products are delivered to foreign markets, various products are imported from outside and storage is made. Harbors as the points transferring information, cultures, innovations between civilizations not only from the functional but also from social aspects as well, have an impact on the economic and social lives of towns while they are supported by the buildings such as walls and castles that have direct effect on the identity of settlements which protect the inhabitants from the threats that may arise from the sea and land. [14]

Kyrenia is an important tourism town of Cyprus, which today featured with its harbor. Kyrenia Harbor, a waterfront settlement developed in the area surrounded by the walls next to the Kyrenia Castle on a land with a slight slope around a natural bay, is used for tourism purposes just like many harbors located in Mediterranean coast and witnessed to Middle Age.

Just like local authors, the foreign authors have given information in many works on Kyrenia harbor; Castle, Bellapais Abbey; St. Hilarion Castle etc. In many texts included in aforementioned works, the tone that was used is very tempting in terms of tourism.

...Sixteen miles from Nicosia is Kyrenia, with its twelfth century Castle guarding the harbor and four miles eastward the wonderful Abey of Bellapaise, one of the finest examples of Gothic architecture in the Levant. At Kyrenia, as indeed anywhere on the coast, there is excellent bathing. Above, on the crest of the mountain, is the Castle of St. Hilarion....and today, those who climb to the queens window, pause to reflect that Aphrodite may yet be the presiding genius of this Castle of Amoures... Kyrenia, is only 30 minutes drive from the capital. It's idyllic tiny harbor, its pretty small houses and its famous castle attract many foreigner seeking peace and seclusion...[15]

This work, which was prepared with the contributions of different writers, was published and handed to tourists with the contributions of Greek Cypriot Ministry of Trade and Tourism. This book as a tourism guide tried to promote the Kyrenia which is 16 miles away from Nicosia, its Castle, Kyrenia Harbor and its surrounding, Bellapais Abbey located on the eastern crest with a Gothic architecture and tempting view; St. Hilarion Castle; small houses distributed in the town and quite beautiful, relaxed and romantic harbor by using pictures.

Another printed publication, which was frequently used by the Cyprus Tourism and Travel Agencies Association, is 'See the Pearl of the Mediterranean Cyprus; An illustrated Guide and Handbook of Cyprus'. Some of the sentences given in the book on Kyrenia, harbor and surroundings and visitors are as follows:

Kyrenia has long been the most popular seaside resort in Cyprus for setters from abroad. Before the war it was a haven for retired English people who found that the absurdly low cost 
of living they could live a princely life on a small pension. Most of them come just to winter there and usually stayed in hotels, but many also settled permanently in or around the town, up in the hills, or even in some villages... Kyrenia town retains an unspoilt beauty, with its old houses and narrow alley-ways circuling the tiny harbor. Yachting is popular at Kyrenia and recent improvements to the harbor, including re-construction of the seawall, looking the harbor is a folk museum.

Arrangements may be made at the harbor for water-skiing and the hiring of goggles. Few people in Kyrenia go swimming without the latter equipment with which to observe the small mountains and grottoes below the sea and the multi colored little fish...[16]

The beauties and living comfort offered by Kyrenia to the retired British people who consider this place as a suitable living atmosphere for themselves, are described in detail as well as the life spaces where they can wander around in the narrow streets and reach to unique little harbor.

The harbors from Middle Age similar to the Kyrenia Harbor that have survived until today, and settlement patterns just behind have created an attraction point for the activities based on water, history and culture together with the physical and social environment that comprise the traces of past. [14]

In the inner space of Kyrenia, while it is possible to see some traces of raftered houses along with their adobe walls, roofs from soil which they were all looked similar, aligned on both sides of narrow lanes in which only horses, mules and camels could pass but ox carts and carriages might have some difficulties, today such areas are in fact raided by bars and discos and had a transformation. First class hotels, guesthouses serving breakfast and hostels; modern restaurants, coffee shops and small sized souvenir shops surround the Kyrenia harbor area almost like a spider web. Kyrenia Harbor has taken the carob storages behind and complains to the sea, which addresses to it with the waves, as if it suffers from the pressure modern restaurants, bars and cabarets. Kyrenia Harbor has become a harbor where fishing and tourist boats, small boats and yachts stay. Kyrenia Harbor which was a host for small sized shipyard and boat makings, is now a haunt for lovers who get emotional by the jazz music until the late hours and walk along, and a walking track for visiting tourists.

Kyrenia Harbor which is one of the Middle Age harbors, has now mainly lost its entry point-exit identity in the town and its business activities, become out of order especially on such purposes, all of which have brought the social percolation in historical pattern together. [14]

Kyrenia Castle and Harbor were assessed in the same platform through the planning amendments and gateways and tried to transform into a tourism oriented development region via the architectural designs of town planning and planning unit of municipality. Today; in parallel with the increase of protection awareness, the environments, which constitute cultural heritage, have generated the approaches that have the objectives of new economic activities and 
use of existing environment in a protective manner. Despite of the efforts for the protection of natural structure of Kyrenia, the Kyrenia Castle and its surroundings could not sufficiently protected with its silhouette, historical structure and image.

Under the 'See the Pearl of the Mediterranean Cyprus', the article on this issue 'Ancient Harbour Defences' describes the Kyrenia Harbor and town in old times:

Presumably Kyrenia, like other towns in Cyprus in the Middle Byzantine Period, was surrounded by a wall as part of its defense system, and concentration would naturally have been centered on the harbor. According to the usual pattern of events these defenses would have been used as the basis for the defense systems in turn of the Franks, Venetians. From what we find today it appears fairly certain that the old defenses of Kyrenia included the castle on the cast side of the harbor and chain of towers on the west side, the whole been linked together by a wall. Three of the old towers are still well preserved one of them situated at the south-west corner of the harbor, another behind the municipal market and the third, which comes in to a view on turning westwards in to the town from Nicosia, situates on the north side of the site of the present church of Archangel, and yet another on the site of the customs house in all likelihood there were others as well. The small town, which stands almost in the center of the harbor, was a part of the old harbor works. It probably stood formerly at the entrance to the harbor and one end of the chain which closed the harbor at night in times of danger was hooked on to it. [17]

The formation of surrounding of Kyrenia and harbor goes back to very old times. When many history researchers try to explain the historical ruins which have reached until today around Kyrenia and Harbor area, we can observe that they deliver very similar comments and remarks.

In Byzantine period, Kyrenia, like other district centers (Nicosia, Famagusta), surrounded by the walls for the defense purpose. The city center and dense settlement area was Kyrenia Harbor and its surrounding. This order of town had reached to Lusignan and Venetian periods together with the works. The walls, which provides the protection of town with Kyrenia Castle and surrounds the harbor from east-west direction jointed to one another, were majorly demolished due to war destruction and also for the requirements such as the expansion of town. Only three wall towers have been protected and managed to reach until today one of which is located on the southwest of harbor, the other is behind the old bazaar-market area (bandabulia) or municipal market; and third one is located on the southern part of city towards Nicosia but almost 250 meter away on the drive. It is possible to see the trace of Kyrenia wall ruins at rear front of old carob-olive ad olive storages that surround the Kyrenia Harbor in almost a moon shape, and at the entrance and end point of harbor. The tower where the lighthouse was placed in the harbor was partially destroyed but nearly combined with the breakwater wall. It is known that the foundation of Archangelos Church, which was constructed on the southern front of harbor, is an old wall tower. The church was placed on the foundation in the way to see the harbor fronts in its current high position. The coastline of harbor, leaning against the castle in 
a moon shape, which goes up to the hotels area, runs along to Karaoğlanoğlu, Alsancak, Lapta, Karşıyaka and Sadrazamköy, Kayalar; Cape Kormacit through quite rocky, rough sea, hacky extensions. The remaining stones from the demolished walss were used in the re-planning of city.

During 1571 Ottoman-Venetian wars, the Kyrenia Castle had exposed to so little damage. Both Lusignans, Venetians and Ottomans had performed many planning activities for Kyrenia Castle, Kyrenia Harbor and town during their rule; and constructed new additional buildings. The arched stone bridge that connects the Kyrenia Castle above the walls is typically an Ottoman work. We can clearly see the buildings from Ottoman times on both sides of streets and the prayer building known as Agha Cafer Pasha Mosque next to it; wall cistern and water springs; Kitabeli Kavizade Fountain and Turkish cemetery ruins.

Today, the buildings in the harbor settlements because of tourism and use of street spaces have undergone a change as the reflection of current living habits and demands. The historical pattern and ecological structure have not yet completely destroyed, our Kyrenia town, which have started losing the buildings from its historical background, now has a cosmopolitan outlook especially around Harbor and its surrounding; and is visited by the tourists from important, well-known and various nations around the world. While inhaling the smell of sea and fish at the harbor and tickling by the movements of small boats hitting to the land with babbling; both local and foreign tourist walk from one end to another in this island, create a friendly atmosphere all year around and experience romantic and unforgettable memories. Kyrenia harbor is the cradle of such life and approaches.

Researcher- writer Rubert Gunnis has given wide coverage to Kyrenia and it s harbor in his book called Historic Cyprus. In the introduction page of his book, the statement of British Prime Minister of 1878s regarding the whole Cyprus is mentioned:

'Cyprus... a land famous in all ages. The Rosy Realm of Venus, The Romantic Kingdom of the Crusaders.' (1936) [17]

Beaconsfield, who was coming from Jewish origin and known as Benjamin Disraeli and then got the title of 'Lord', had included explanatory information on the island of Cyprus and its settlements under his work written in 1847, called 'Tancred'. Cyprus, from the first day of its existence, had always a reputation in history; was a host for Venus; identified with Crusades.

We can mention the findings of writer Rubert Gunnis who highly adopted and cared about this idea of Beaconsfield, regarding Kyrenia and its Harbor by making some quotations: First of all, he featured the historical importance of Kyrenia Castle in the formation of Kyrenia town. He wrote that the wife of King I. Henry 'Alix de Montferrat' died in this castle and buried following a ceremony at Agia Sofia Cathedral in Nicosia. The castle had also become more important from this perspective. For Kyrenia Harbor, he stated that:

...the little harbor of Kyrenia has, since the British Occupation, been furnished with a quay and seawall. In the center are the ruins of an ancient lighthouse, the path to it from the shore beign formed of circular inscribed Roman Cippi: [17] 
It is noted that the dock or fishing pier located at Harbor was built during Colonial Period; a wall in the means of pier (breakwater) that protects the waves to come ashore on the harbor side facing the sea, serves as a shelter for the boaters was put up and an old lighthouse was constructed on top of it. The stated wall is now transformed into a condition that can be used for walking. In the past, the cars were also allowed in that area as well as pedestrians.

The official publication of Cyprus High Commissioner called 'A Handbook of Cyprus' that was jointly prepared by Sir. J.T Hutchinson, Head of Ceylon Supreme Court, M.A and Claude Delaval Cobham C. M.G, who was the Larnaca Commissioner during the early years of Colonial Period includes the history of Kyrenia Castle under the article called either 'Kyrenia' or 'Keryneia' and explains that the town is a fisherman settlement area founded around a small bay (pit).

A large sum of money was spent between 1886 and 1892 on the eastern break water and quay, but the anchorage is still unsafe during a N.E wind. [18]

It mentions that between the years of 1886-1891, the Colonial administration had spent too much money on the Kyrenia Harbor to built a breakwater on the eastern part of harbor, a pier and dock for the fishing boat to drop anchor and be protected from the severe storms.

The Cypriot author Rina Castelli included the history and current situation of Kyrenia, Kyrenia Harbor and its surrounding in her Kyrenia monograph:

Before going on further with the historical events, Kyrenia town itself deserves some attention. During the $13^{\text {th }}$ century the town did not cover a large area. The western boundary was the church of the Archangel Michael.

The Lusignans always constructed round towers, and several have survived until the present day. One is in Eleftheria street (Canbulat Street) and has beautifully fluted (cannelures) projections on which are supported the samparts with the embrasures (maechicoulis). (illust. 25). It is closely surrounded by buildings and one has go to inside to see it properly (illust. 26). According to $\mathrm{H}$. Peristianis, at the beginning of the $20^{\text {th }}$ century a certain Kyrenia citizen bought the tower from the Turks and proposed demolishing it. Fortunately it was bought and saved on behalf of the government by the their High Commissioner to Cyprus, Sir H. Bulwer. The best maintained tower of the walls is Camouza or Coulas. Florio Boustronios refers to this tower as the one near the gate, calling it 'La volta di Canusa.

These three towers, the Archangel, La mouza and that in Eleftheria Street are in a straight live and it is certain that, joint together, they formed the western city wall. Camouza was at the northwestern point Kyrenia. From there the wall was joined to the castle. The main entrance to the city was in the wall on the southern side. The name Camouza in stone have been found in this area. It was the custom of the Venetians to place status of lions at the gates of a city. Some of these fragments are at present in the castle courtyard white washed. If the administrative headquarters where not actually with in the castle they were in the fourth wall. This may be 
concluded from the fact that Turkish 'Konaki' was this area, at the eastern and Grivas Dighenis Street (Ecevit Avenue), and the judicial and administrative authorities were in this building. Georgios I. Georgiou made a sketch of the building from descriptions given to him by old residents and this shows it as having round, latticed windows of pour Gothic form... [19]

Rina Castelli has some findings that there have been some variations of the word Kyrenia in certain periods of history. Namely: Ptolemeler: 'Keronia or Keravnia'; Diodoros: 'Kerynian', Skylax: 'Keryneian (Periplous p.48)'; Byzantine Stephan: 'Kirynian’; Plinos: 'Cinyriam’; Constantine, Propyrogennetos: 'Kiryneian (p.39)'; Hierocles: 'Kyrinian’; Macharias and Boustronios: 'Kerinian and Kirinian'; Geography scientist Meletios: 'Keronian and Kerini'; English books on Cyprus: 'Kerynia or Kerenia.' [19]

Some important registers showed that instead of 'Kyrenia', the word 'Edirne' was used in Ottoman period. The 'Kyrenia Gate' in Nicosia was named as 'Edirne Gate'. Today Turkish Cypriots pronounce as 'Kyrenia' while Greek Cypriots as 'Cerinya'.

The Kyrenia settlement was a very narrow area in early years and mainly concentrated around castle and its surroundings. This area had expanded in time and grown in the direction of Lapta and Esentepe along the coat line. Kyrenia Harbor and around the castle now reflect a tourism based living environment through its ancient visiting area image.

The area where the Archangelos Church was located was the western border of city since XIII century. When we consider the current borders of Kyrenia, the Archangelos area is way more within the city.

The following remarks were included under the Kyrenia Monograph of Rina Castelli that she wrote through some inspiration from various published references: The Lusignan period of Kyrenia was mainly the period when the town was surrounded by the city walls and towers. Social life had improved after the walls were destroyed in time; old and new buildings remind a neighborhood competition from old to new one within another. Three wall towers or fort wall which are the evidence that the town was surrounded by the walls once, formed the surrounding of town with the same walls connected to each other and integrated with castle walls. During that period, it was possible to enter Kyrenia, which was surrounded all around, from the southern side of walls. Currently both the three wall towers and even city walls are demolished; their stones were used in the construction of modern buildings. The social life of Kyrenia has affected from the modern life and become a cosmopolitan center that is closed to past.

The castle was surrounded by a moat filled with water in times of danger. There was a permanent internal harbor at the western end of the moat in which galleys were repaired or withdraw in times of extreme danger. It is believed that the entrance to the inner harbor was under the archway visible today below the custodians Office. Than the harbor entrance was not open to the east but open to the north. Shaped like a horseshoe. The eastern arm was the Coulas, and the western arm ended in the tower part of which is today the Customs House. According 
to reliable historical sources, the entrance was closed in the time of danger, and probably every night; by means of a heavy chain. [19]

The Kyrenia Castle that used to be surrounded by the walls, had undergone some planning alterations around castle and it surrounding due to the public space needs at the end of Ottoman period and in the early years of Colonial period. Particularly the western part of castle was transformed into the shelter of galiots, galleys or warships with more oars; and fishing boats. The trough on this side of castle was filled with rocks for the protection from sea storms, wind or extreme waves. Such mounds partly separated the castle and sea in XX century; the surrounding was made suitable for coastal stroll; now it has become an area where vehicles, most of fishing vehicles can easily enter and park.

The bridge that was constructed and ensured the entrance to the castle in Ottoman Period by using stones and kalash, primarily constructed in the way that would ensure an access above the trough located around the castle. The northern past of mentioned bridge was opening to the shore, which is now the closest entrance to the castle. The people crossing under the bridge was directly reaching to the sea, shore. In this area, especially the big galiots were repaired; broken ruins of many small boats, boat and fishing barges that were worn off and not used were placed there.

After the development of island economy on the basis of tourism sector has become a government policy, a series of development-master plans and designs have been prepared and the upper part of castle bridge was asphalted and small buildings were constructed on the fort; the lower part of bridge and its surrounding have been subjected to the planning. A guard cabin made from stone was added under the bridge for the control and protection purposes during the entrance to the harbor; a patio or gateway was built to ensure the travel of pedestrians or pack animals afoot on the harbor line all along.

The gateway that was launched in Ottoman Period and established for public needs, war, defense; marine transport and fishing requirements at Kyrenia Harbor had been gradually expanded. During Colonial Period, some alterations based on the 'colonial style' planning and town planning was performed within the Kyrenia Harbor. The Customs Building that is located on the western part of Kyrenia Harbor and serves now as a historical visiting spot is one of such developments. People who would travel the coastal countries on the opposite shore of island such Alanya, Mersin, Syria via Kyrenia Harbor, were carried out their customs procedures there and leave the island. During the early years of Colonial Period, the entrance to Kyrenia Harbor from the eastern side was not allowed. This applies also for the final times of Ottoman Period. The western side of harbor was used as an entrance point to the harbor after the construction of Customs Building.

The Kyrenia Harbor shore was subjected to the planning regulations through filling materials and reinforced concrete construction and infrastructures in the way to resist to sea waves; 
gateway areas were extended and transformed into a horseshoe shape. Due to safety reasons, the entrance links at the Kyrenia Harbor were closed from time to time by placing barriers and barricades with thick and big chains.

The historical texture of Kyrenia Harbor could not appropriately protected. This harbor, which gets visitors and tourist all around world, has undergone the pressure of some public space requirements due to economic conditions; the protection of harbor in its original status.

When the coastal settlements in Mediterranean region also covering Kyrenia are looked into, the most important physical space elements that establish functional setup are harbors and their piers. The living is water-oriented and trade is confined with fishing ports as well as warehouse units, which are used to store the special products of settlements. The carob and cereal storages going all along the waterfront are the built spaces used for local functions of settlement. In 1930s, the waterfront path was taken from the cliff between the storages and sea surface; while cliffs was transformed into a built area, the storages do not have any contact with the water. After tourism had started to be active in local economy, the storages without any contact of water have become restaurants, tour offices and cafes. [14]

The Kyrenia Harbor now has a way more different image when compared with Lusignan, Venetian, Ottoman and Colonial Period and has become a modern town and settlement after the pedestrian walking trails have expanded, carob and cereal storages have transformed into guesthouses, hotel or accommodation place, the ground floors of such places have been allocated for restaurants, café-bar and disco, development of rear fronts of storages into modern buildings by using construction materials, paving stones were removed and asphalted.

Kyrenia Harbor has become a space where the mass size and front characteristics of buildings within have deteriorated due to tourism and modern living habits; the spaces that were functioning as housing and storages have changed in their uses to meet needs for the food \& beverage and trade units aimed at tourism activities and sufficient bed capacity for the accommodation, some parcels are combined and become accommodation units as hotel and motel, the soil floors of gardens of food \& beverage buildings were covered by concrete materials to put table during summer season.

Today, the planning activities of Kyrenia Municipality behind the castle, theatre building, beaches as well as shops and shopping centers that are under construction; the building above the fort which was recently used as Police Building and Prison; private housing and restaurants developed on the buildings surrounding the harbor; car park area on the fort just next to the stone bridge that enables castle entrance and similar activities have caused major changes in the ecological and historical texture of Kyrenia Harbor. It is already possible to foresee that with the justification of public space, such major development activities will keep coming and destroy the historical texture and beauties accumulated in centuries. 
Architect George Jeffery, F.S A. who is known for his researches on the whole island from the archeological and architectural aspects, underlined in his historical findings regarding Kyrenia, Kyrenia Castle and harbor that similar processes have happened before. [20]

From the point of fact that while there is an older for an old, and a newer for new period, the change in town and harbor is the realization of destruction of past to some extent and performance of new initiatives with modern understanding and buildings for future.

Since Kyrenia is a coastal town, it catches the attention and admiration of tourists in a short time. Kyrenia, apart from its Harbor and castle is a town that offers mind-blowing opportunities to the tourists with its café and restaurants, small guesthouses, glamorous architecture and history.

Tourism reality and economic expectations are signification reasons for fast development and increase of changes based on the investments that may damage the historical texture and natural structure of town and modernized planning.

Many scientists, who make reviews on urban spaces and settlements have accepted that historical texture that is constituted by ancient buildings have become complicated with the modernized building additions due to public space requirements.

The problems concerning the urban spaces have arisen in the second half of $20^{\text {th }}$ century for the first time; the physical and soci al environment problems, which are caused by the approaches that do no consider the outer space during the design of buildings in the perspective of modernist practices, have been the outstanding issues in the relevant discussions. After modernism, there are also various simultaneous factors that shape and change the nature of urban life. When it comes to the nature of urban environment, the first thing to be remembered is that the city is for people. Pursuant to laying a basis for the communication and activities of people, urban public spaces are the most important tools for the realization of these functions. The revitalization of social unity and urban life is partly related with the relationship of structural style with outer spaces and the hierarchy, diversity and characteristics of these spaces. This is not a simple quantity or size issue, in fact it the complex interpretation of characteristics, psychology and figurativeness of spaces. Public spaces are like the mirror of city community and reflect local culture and living time and give hints about the social and economic status of local community. Organic urban texture, which covers spatial definitiveness and social meaning in traditional settlements, shows through its past uses that public spaces are significant parts of life. However; when we look to the current situation of our cities, particularly the public spaces have lost their significance as the heart of city and generally have business functions. The public spaces in new established areas are the spaces that are left, meaningless and unpractical. . [21] This approach of Prof. Dr. Derya Oktay, Eastern Mediterranean University Faculty of Architecture Lecturer, may also be considered for Kyrenia town and Kyrenia Harbor. 
It is explicitly known throughout the history that coastal towns, especially the harbors have major roles in the social life. When the Kyrenia and its harbor, which have important roles among the public spaces in Cyprus, are reviewed, despite the meaning until today and featured significant historical buildings, many places of town now present a different dimension; 'old and new' impressions are almost in conflict. Because of its tourism potential, Kyrenia with its history and cultural heritage is the home to tourism investors and buildings that are more offer service to this sector.

As a Middle Age harbor, which established in early centuries but got its current outlook from the Middle Age, Kyrenia Harbor, which is within the distinctive topography of Cyprus, a part of Eastern Mediterranean geography, is the hub for studies and activities based on water, history and culture around its physical and social environment that bears the traces of past. These environments with such cultural heritage are taken under protection as protected areas while their economic requirements are brought necessarily forward.

The future generation will not be able to see regional past based cultural heritage against the settlements that can develop with coastal life culture and tourism. Recently the historical houses that are close to Kyrenia Harbor, which serves for business functions as sea transportation and fishery, have been repaired and available for use. . [14]

\section{CONCLUSION}

The historical Kyrenia Harbor that brings out the town of Kyrenia was used to be a natural coastal line as a bay. It was a bay where fishing boat could fit in easily. There are also some people stating that during the early times of history, the Kyrenia town developed because of this bay.

It is definitely obvious that the reason of choosing this bay to construct Kyrenia Castle and walls was on the basis of a historical requirement. According to the observations of foreign travelers, before the Byzantine period, the harbor, which is an important bay of Kyrenia coastal line, was an appropriate spot for the boats and galiots to approach and go ashore. Many tribes that were considered the Kyrenia town as a site made a lot of planning contribution under that period's conditions and opportunities to make this bay be more practical. It is possible to see such changes from the fossils of environmental structuring and archeological findings.

Kyrenia Harbor, which was transformed into a Harbor through the civilization that was brought to the region by the ruling tribes or states in the Island, was recorded with the discourses of Kyrenia Coast Bay, Kyrenia Castle Suburb, Coastal Line, Kyrenia Ancient Harbor, Kyrenia Marina, Kyrenia Tourism Harbor.

Both the planning like activities the first settlers of Kyrenia, 20-km distance away from the capital Nicosia, on Harbor development and many ruins of liveable buildings and planning activities done by Byzantines AD in Kyrenia and appropriate bay on the coastal line have reached to until today. 
In 1149-1498 Lusignan Period, the city walls and towers in the way of covering Kyrenia Castle were constructed. The Kyrenia community as divided between walled and out of the calls, had frequently used this bay for their ships to edge in with; they had placed boat shelters and unloading platforms together with wooden piers.

In 1489-1570 Venetian Period, this bay of coastal line was transformed into a harbor, wooden piers were improved; the first foundation of breakwaters were laid against the extreme waves from the sea.

In 1571-1878 Ottoman Period, Kyrenia Ancient City and Harbor were developed under the impact of Turkish-Islam civilization. The traces of Turkish-Islamic civilization, its cultural heritage in numerous works are distributed in almost everywhere in the Island which stayed under the rule of Ottoman for 307 years. Ottoman Period was the most concentrated time of planning activities for the development of Kyrenia and its Harbor. During this period, Kyrenia and Harbor was integrated with each other; ruins from the destroyed and wrecked walls were sorted out and the stones that could be used in planning activities were kept and accumulated on the points close to the bay at the shore via carriages and similar vehicles. Camel, horse, donkey paths were built along the way going from the coast to behind the storage buildings and suitable to go outside Kyrenia. First soil paths then stoned paths, lanes and gateways were built after the hills that evolved from Bellapais to St. Hilarion direction lowered in phases towards the sea; and the valleys that shaped due to climate conditions, allowed to go down to the coast. Tremithiya (Doğanköy); Kazafana (Ozanköy), Templos (Zeytinlik) crests and Kyrenia Harbor and villages connections via these gateways. The road, paths from the past that may reach to Bellapais crest and Doğanköy and Ozanköy are still available to use. It is possible to follow these gateways from the maps of Lands and Surveys and protection areas.

It is known that the areas where Dome Hotel was built on the opposite direction of castle and behind the castle are farmlands. The construction site of Rocks Hotel was like a bay located adjacent to the Kyrenia Ancient Harbor where the river basin coming from the crest of Doğanköy meets with the sea.

We can learn the stories behind the numerous wrecked ship parts at the entrance of harbor as kayak, galiot repair places (shipyard activities) from the recent generation who can remember and tell.

Some alterations had been made on the city walls that were parallel to the Kyrenia Castle and trough; pedestrian downhill were built.

The region particularly where Agha Cafer Pasha Mosque was constructed was converted into housing zones by lowering a part of walls that were parallel to Castle on both sides and placing gateways; exclusive barns were built around the mosque for the animals of guests coming for the Friday Prayer; water channels, cisterns and fountains were densely built. The traces of Kavızade Fountain; Muhassır Mehmed Emin Efendi Cistern; the cistern located out 
of the castle ditch behind, at the area of Baldöken Cemetery crest that goes down to the coast; a gasilhane (a place where the deceased are washed and prepared for burial); the building connecting the aforementioned buildings and used as Turkish Bank today and trestles that make the water connections on the foundations of Kyrenia Municipality Building are still possible to encounter. When we look at the current position of Kavizade Fountain, it is just under the stone gateway that goes downhill, located very close to the Mosque but it is almost squeezed between two gateways. The planning alterations of Colonial Period were mainly focused on such Ottoman works. Baldöken Cemetary behind Kyrenia Castle and Harbor; Garyöler Cemetary; Muhassir Mehmed Emin Efendi Cistern, water arcs behind the castle and Kavizade Fountain created by draining to the Agha Cafer Pasha direction; and water distribution network were undergone change in time by the interference of British. Baldöken Cemetery was subdivided; Court Buildings were constructed. The gateway going in front of Agha Cafer Pasha Mosque Kavizade Cistern down to the coast was turned into a road. St. Andrew Church was built inside of Islam Cemetery on the hill behind the Kyrenia Harbor. The office building, which was used to be Kyrenia Police Station and now used for military civil works, was developed by the British and converted a police station that supervise Kyrenia Castle and Harbor. The route between Kavizade Fountain and Agha Cafer Pasha Mosque was subjected to road expansion; shops and some buildings all along were demolished and used as underground material.

Major W. N. Balton, who was appointed to Kyrenia District Commissioner on $20^{\text {th }}$ October 1908 by Cyprus High Commissioner C.A King Hanman in accordance with the applicable 1894 British laws, had supported that the town of Kyrenia should have improved under the Colonial Administration conditions. Aside from the historical characteristics of Kyrenia due to being a coastal town, the acceleration of development and its organization in the framework of planning principles were mandatory .... [22]

During the Sabri Efendi times, Kyrenia Harbor was planned in its closest situation as today; Kordonboyu was organized. There is a great effort and contribution from Cypriots but especially from Turkish inhabitants on the foundation and development of Kyrenia Harbor.

When we compare the past and present of Kyrenia Harbor, it is possible to see some differences from the planning and utilization aspects. While it was a quite bay and suitable coast platform close to the Castle where fishing boat easily come ashore and unload; now the development and change of uses at the harbor stand out.

The Harbor reflects a cosmopolitan view with the tourism facilities along Kordonboyu that employ people from different cultures. While there is an Italian music on one side of Harbor; on the other side, the tourists from different races eat their French or Italian meals and enjoy themselves in reverence, and it is also possible to observe Far Eastern chefs cooking Chinese dishes and their tables waiting for customers. The Kyrenia Harbor presents us the wait of people from different countries for their Nescafe, Cappuccino, Cacao, Latte and tea; the looks of people, who walk at Kordonboyu, meet randomly and local and foreign tourists to each other 
as if they know one another; chestnuts at Kordonboyu, cotton candies, handcrafts displayed and sold in stalls; handicrafts such as rings, beads, bracelet, snoods, scarves; souvenirs, Kütahya tiles, evil eyes, colorful lamps as well as local Cypriot sweets and delights. From this aspect, it went beyond being a shelter for fishing boats and has become a place where different cultures are dominant; Harbor, which was only considered as a beautiful and pretty harbor, has almost lost its historical texture and its past has faded away.

Knowing that Kyrenia Harbor is a marine, the promotions of Harbor via media and press in accordance with the international presentation and activities inside harbor and aims and benefits of world tourism sector are way different from the reviews and promotions in the past. Kyrenia Harbor is promoted with an understanding and approach as if it is just constructed for the yachts.

The changes in Kyrenia harbor and city may be acceptable by town planning standards.

While the acceptance of historical continuity in the formation of cities is not abstract, the civilization created by human life and its continuity together with the change and development of cities in their forms during this process either exist with their societies or disappeared from the world in time.... [23]

The various changes in Kyrenia and Harbour due to economic factors, social activities, tourism and changing population and cultural diversity may be acceptable. Despite of all these developments and changes, it is always known that Kyrenia and its Harbor is an enriched town and harbor on old foundations with a cultural heritage, its color, texture, existence, style, uniqueness and architectural buildings.

Environment is the statement of a culture. It reflects the tendencies, class structure, economy, aesthetic tendencies and even worldview of the dominant culture. The change in environment is the statement of culture changes. Environment reflects a historical background. City is a historical background. Correct and detailed analysis enables us to assess it as a historical document. . [24]

Although in accordance with the law, the historical texture of city of Kyrenia and surroundings of harbor are under protection, the historical references of urban space, which still a symbol for Cyprus in its new status, have been damaged and urban and collective memory that go back to centuries, and public spheres as one of the most important components, have been constrained to transform.

While city surroundings represent the symbolic and spatial representation of social forces, Habermas (2012) [11] analyzed the evolution of media from the early $18^{\text {th }}$ century until today by following the occurrence of public sphere and further development. Public sphere has become a public argument where the subjects that everyone is interested in, can be discussed and ideas are shaped. If one cannot communicate, he cannot make relationships; thus the common meanings of symbols disappear due to the decrease of sharing between individuals and society. Them people start to look for new symbols, and the situation of having lack of symbols and symbolic combinations cause deterioration in social structure and lead to disintegration. [25] 
As reviewed by this study, the idea that the only way to protect the City of Kyrenia and surroundings of harbor in the scope of tourism, is to concentrate only on entertainment, shopping, food \& beverage places, pushes the historical environments to handwringing and even destructive process. Such habits of modern life have introduced a process that deteriorates, soils ecological, cultural and social environment values. In tourism, the feature of attraction in a settlement is based on having traces of past and maintaining natural and social environments without any deterioration. In this perspective, meeting the needs of people today without making any sacrifice from the opportunity of future generations to meet their needs should also be taken into consideration within the context of Island of Cyprus as well as city of Kyrenia and its harbor, and sustainable steps should be made. [14]

\section{References}

[1] Kiper, P. (2004). Küreselleşme Sürecinde Kentlerimize Giren Yeni Tüketim Mekanları ve Yitirilen Kent Kimlikleri, Planlama, 4, 14-18

[2] Özkan, M. (2012). Kamusal Mekanda İktidar Baskısı ve Direniş Olanakları, Mimari tasarım ve Eleștiri, 1

[3] Öztürk, R. (2013). Beşparmak Olgusu ve Kıbrıs. Türkiye Dergisi

[4] Kuban, D. (1968). Anadolu-Türk Şehri Tarihi Gelişmesi-Sosyal ve Fiziki Özellikleri, Vakıflar Dergisi, v. VII., 54-78

[5] Kuban, D. (2000). Tarihi Çevre Korumanın Mimarlık Boyutu, İstanbul: Yem Yayınları

[6] Fehmi, H. (1987). Kuzey Kıbrıs Türk Cumhuriyeti El Kitabı. Lefkoşa

[7] Rosi, A. (2006). Şehrin Mimarisi, N. Gürbilek, İstanbul: Kanat Yayınları

[8] Boyer, C. (1998). The City Of Collective Memory, Cambridge: MIT Press

[9] Ülkeryıldız, E. \& Önder E.C. (2013). İzmir Kent Temsilinde Sinema İle Üretilen Kolektif Bellek: Yeşilçam Örneği, EgeMimarlık, Eylül, 30-33

[10] Çalak, I.E. (2012). Kentsel ve Kolektif Belleğin Sürekliliği Bağlamında Kamusal Mekanlar: ULAP Platz Örneği, Almanya. Tasarım+Kuram, 13, 34-47

[11] Habermas, J. (2012). Kamusallı̆̆ın Yapısal Dönüşümü, (Çev. Mithat Sancar ve Tanıl Bora), İstanbul: İletişim Yayınları

[12] Hakeri, B. H. (1983). İlginç Olaylar ve Tarihi Eserlerde 1570'e dek Kıbrıs Tarihi. Lefkoşa

[13] Mariti, Giovanni; Viaggi Per I'isola di Cipro; Italy, 1769 (This work of Claude Delavel Cobham 'Travels in the Island of Cyprus'; was published in English in 1909)

[14] Hamamcıŏ̆lu,C. \& Kerestecioğlu, F. (2007). Akdenizde Topoğrafyasını Koruyan Ortaçağ Limanları ve Turizmin Çevresel Etkileri: Alanya Hisaiçi Mahallesi, Antalya İçkale Mahallesi, Girne Tarihi Liman Mahallesi, Megaron YTU Arc. Fac. E-journal, 2-2, 108-132

[15] Limbourides, A. (1967). Cyprus, The Island of Aphrodite. Nicosia 
[16] Colocassides, M. G. (1964). See The Pearl of the Mediterranean Cyprus; An Illustrated Guide and Handbook of Cyprus. Nicosia

[17] Gunnis, Rubert. (1936). Historic Cyprus; A Guide to its Towns and Villages, Monasteries and Castles; (inner cover and main title). England

[18] Hutchinson, Sir J.T. \& Cobham, C. D. (1907). A Handbook of Cyprus. London

[19] Castelli, R. (1974). Kyrenia, A Historical Study. Cyprus

[20] Jeffery, G.F.S.A. (1918). A Description of the Historic Monuments of Cyprus Studies in the Archeology and Architecture of the Island with Illustrations From Measured Drawings and Photographs. Cyprus

[21] Oktay, D. (2007) March-April. Kentsel Kimlik ve Canlılık; Dosya: Kentler ve Meydanlar. Mimarlik Dergisi.

[22] Altan, M. H. (1986). Belgelerle Kıbrıs Türk Vakıflar Tarihi, Kıbrıs

[23] İnceoğlu, M. \& Tokman ,Y. L. (2103), Şehircilik; v.7; Anadolu Üniveristesi

Kayın, E. (2006). Bir Kamusal Alan, B,r Kentsel Simge, Bir Kıyı Hikayesi: Kordonboyu, EgeMimarlik, 4-59, 18-21

[24] Dağlı, U.U. (1999). Kıbrıs Sokaklarında Mimariye Yaşama Ve Çevreye Dair, Lefkoşa: Işılk Kitabevi Yaymları

[25] Dönmez M.E. \& Ak1, Altan. (2005). Megaron YTU Arc. Fac. E-journal, 1-1, 108-132, 67-87

Falay, N. (2104). Kamusal Alanın Oluşumu, Dönüşümü ve İktisadi Boyut, Journal Of Life Eceonomics, 2, 51-70

İçli, G. (2011). Kentsel Dönüşüme İlişkin Sosyolojik Bir Değerlendirme-Denizli Örneği, Sosyal Bilimler Dergisi (online), 3-1, 43-57

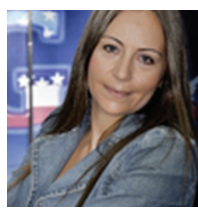

Ümmü ALTAN BAYRAKTAR - ummubayraktar@gau.edu.tr

Ummu Altan Bayraktar was born on 15th of January 1978, Nicosia - North Cyprus. She had completed her BA degree in Faculty of Economics and Administrative Sciences at Uludag University, Department of Business Administration (2000). Then, she completed her MSc in International Business and Management at Sheffield H. University, UK (2002). In 2003 she was accepted for the PhD Program at Graduate School of Social Sciences, Department of Sociology at Middle East Technical University (METU) and she attended to the program for 1 year. In 2004 she started the PhD Program at the Faculty of Communication at Ankara University, Department of Public Relations and furthermore in 2010 she received the PhD degree. Her thesis focused on The Cyprus Conflict and the Annan Plan: reflecting the point of view of both Turkish and Greek Cypriot Press. 
